\begin{tabular}{cc|c}
\hline Tar. Bil. Der. & Journal of Agricultural Sciences \\
& $\begin{array}{c}\text { Dergi web sayfası: } \\
\text { www.agri.ankara.edu.tr/dergi }\end{array}$ & Journal homepage: \\
& www.agri.ankara.edu.tr/journal
\end{tabular}

\title{
E-Ticaret Yoluyla Gıda Maddeleri Satın Almaya Yönelik Tüketicilerin Tutumunu Etkileyen Faktörlerin Analizi
}

\author{
Murat SAYILI ${ }^{a}$, Akif Musa BÜYÜKKÖROĞLUa \\ ${ }^{a}$ Gaziosmanpaşa Üniversitesi, Ziraat Fakültesi, Tarım Ekonomisi Bölümü, Taşlıçiftlik Yerleşkesi, Tokat, TURKiYE
}

ESER BILLİSI

Araştırma Makalesi - Tarım Ekonomisi

DOI: 10.1501/Tarimbil_0000001212

Sorumlu Yazar: Murat SAYILI, E-posta: muratsayili@yahoo.com, Tel: †90 (356) 2521616

Geliş Tarihi: 07 Kasım 2012, Düzeltmelerin Gelişi: 01 Şubat 2013, Kabul: 15 Şubat 2013

\begin{abstract}
ÖZET
$\mathrm{Bu}$ çalışmada, Tokat ilinde yaşayan tüketicilerin e-ticaret yoluyla gıda maddeleri satın almaya yönelik tutumlarını etkileyen sosyo-ekonomik faktörlerin analizi amaçlanmıştır. Bu amaçla Logit modeli kullanılmış ve 277 tüketici ile yapılan anketlerden elde edilen veriler kullanılarak model tahmin edilmiştir. Analiz sonuçlarında tüketicilerin aylık ortalama gıda harcaması 555.70 TL olarak belirlenmiştir. Tüketicilerin \%34.66'lık kısmı e-ticaret işlemlerine güvenmektedir. Araştırma sonuçlarına göre, aylık gıda harcaması arttıkça tüketiciler e-ticaret yoluyla gıda maddesi satın almaya yönelik olumlu tutuma sahip olmaktadır. Oluşturulan Logit modele dâhil edilen açıklayıcı değişkenlerden aylık gıda harcaması, güven ve eğitim seviyesi istatistiksel olarak anlamlı bulunmuştur. Buna göre tüketicilerin aylık gıda harcamas1, eğitim seviyesi ve güven duygusu ile olumlu tutuma sahip olma arasında pozitif yönlü ilişki olduğu ortaya çıkmıştır. E-ticaret yoluyla gıda maddesi satın alınmasının artırılması için özellikle tanıtıcı faaliyetler yapılmalı ve güven ortamı oluşturulmalıdır.
\end{abstract}

Anahtar Kelimeler: Gıda maddesi; Satın alma isteği; E-ticaret

\section{Analysis of Factors Affecting the Attitudes of Consumers on Food Purchasing Through E-commerce}

\section{ARTICLE INFO}

Research Article - Agricultural Economy

Corresponding Author: Murat SAYILI, E-mail: muratsayili@yahoo.com, Tel: +90 (356) 2521616

Received: 07 November 2012, Received in Revised Form: 01 February 2013, Accepted: 15 February 2013

\begin{abstract}
ABSRACT
The purpose of this study was to analyze the socio-economic factors affecting the attitudes of consumers located in Tokat Province on purchasing foods through e-commerce. Logit model was used and an estimator model was developed using the data obtained from questionnaires conducted with 277 consumers. The analyses showed that average monthly food expenses of consumers was $555.70 \mathrm{TL}$ and $34.66 \%$ of the consumers trust the reliability of e-commerce processes. The reliable e-commerce tendency for food purchasing increased with the higher monthly food expenses of consumers.
\end{abstract}


Explanatory variables included to the constructed Logit model such as monthly food expenses, trust and education levels were significantly important. The results revealed that monthly sense of trust; average food expenses and education level of consumers have important relationship with positive attitudes of consumers. E-commerce through the purchase of food, especially promotional activities to increase and secure environment should be established.

Keywords: Food; Purchasing desire; E-commerce

(C) Ankara Üniversitesi Ziraat Fakültesi

\section{Giriş}

İletişim teknolojilerinin ve internet kullanımının hızla gelişmesi, dünyada yeni bir ekonomik düzenin yaygınlaşmasına yol açmıştır. Bilgi ve iletişim teknolojileri ile özellikle internetin sunduğu hız, yüksek derecede verimlilik ve etkileşimin yanı sıra, küreselleşmeyle sınırların kalkması sonucu tek bir pazar yaklaşımı, işletmelerin yepyeni bir ortamda iş yapmalarına sebep olmuştur. Buna bağlı olarak, coğrafi sınırlar ortadan kalkmış, satıcı ile alıcının buluştuğu yer olan pazarlar, farklı bir boyut kazanarak ticari işlemler elektronik ortama kaymıştır. Küreselleşen dünyada, yeni ekonomik sistem içindeki bu ticaret biçimine elektronik ticaret (e-ticaret) adı verilmektedir. Bu gelişmelere bağlı olarak, yeni ekonomi ve e-ticaret, üzerinde önemle durulmasi gereken bir konudur.

Eski ve yeni ekonomiyi farklı kılan yönler, ekonomik özelliklerin değişmesinden ileri gelmektedir. Eski ekonomi olarak adlandırılan ekonomik düzen; kas gücüne, imalat sektörüne ve standart üretime dayalı iken yeni ekonomi beyin gücüne, bilişim sektörü ile esnek üretime dayanmaktadır. Yeni ekonomide, sürekli değişen şartlara uyum ve anında tepki göstermek önemlidir (Çağlar 2009).

Ortaya çıkan yeni ekonominin temel prensipleri; insanları iletişim ağına dâhil etmek, sistemleri açık hale getirmek, eski alışkanlıkları terk etmek, firsatları daha fazla önemsemek ve ilişkileri güçlendirmektir (Taşlıyan 2006). Ayrıca yeni ekonomi iktisadi hayatta, ekonomik işlemlerin kolaylaşması neticesinde maliyetlerin neredeyse sıfırlanmasını sağlamış, pozitif dışsallık oluşturmuş, müşteri istek ve ihtiyaçlarına uygun üretim ile tüketici tatminini sağlamış ve piyasanın şeffaflaşması sonucunda tüketicilere fiyatları kıyaslama imkânı vermiştir.

E-ticaretin ekonomik ve toplumsal hayatta giderek kendisine daha fazla yer edinmesi, ortaya birçok avantaj çıkarmaktadır. Elektronik iletişimin artmasına bağlı olarak firmalar, müşterilerine ve diğer işletmelere hızlı, kolay ve ucuz bir şekilde ulaşabilmektedir. Fiziksel yatırıma girmeksizin, mağazalar ya da pazarlama ağları kurmadan pazarlama yapılabilmektedir. Tüketiciler için ise; işlem maliyetlerinin ve nakliye masraflarının düşmesi, evden çıkmadan ve zaman harcamadan alışveriş, yeni ürünlerin bilgilerine kolayca ulaşabilmek, ürünleri birbirleri ile karşıllaştırarak satın almak gibi avantajlara sahiptir (Uygur 2010).

E-ticaret genel olarak dört şekilde yapılmaktadır. Bunlar, işlem hacimlerine göre sırasıyla; işletmeler arası-ticaret, işletme ile tüketici arasında e-ticaret, tüketiciler arası e-ticaret ve işletme ile devlet arasında e-ticaret'tir (Yazıcı 2002). Türkiye'de işletmeden tüketiciye e-ticaret finans sektörüyle başlamış ve diğer sektörlerde devam etmiştir. Ancak Türkiye'de e-ticaretin gıda maddelerinin perakende aşamasında kullanımı tüketici davranışları ve alışkanlıkları nedeniyle yaygın değildir. Türkiye'de henüz emekleme aşamasında olan e-ticaret yoluyla gıda maddeleri satışı yıldan yıla artmakta ve gelecek vaat etmekte olup, bu konuyla ilgili olarak güncel tüketici profili ile tutumu önem kazanmaktadır.

Türkiye'de e-ticaret kavramı, etkileri, faydaları gibi konularda birçok araştırma yapılmasına (Akınc1 2002, Kaya 2002, Yazıcı 2002, Aksoy 2006, Doğaner 2007, Ene 2007, Albayrak 2008, Boyacıgil 2008, Soydan 2008, Kılıç 2010, Uygur 2010) karşın, e-ticaret yoluyla gıda maddeleri satın almaya yönelik Tokat ilinde herhangi bir 
çalışmaya rastlanılmamıştır. $\mathrm{Bu}$ açıdan çalışma önemlidir. Araştırma alanı olarak seçilen Tokat ili, gıda maddeleri ticareti bakımından önemli bir potansiyele sahiptir. İlde gida maddeleri ticareti geleneksel yollar olan yerel pazarlar, market, süpermarket ve hipermarketlerden yapilmakta olup, internet yoluyla gıda maddeleri satış1 yapılmamaktadır. Türkiye'de gıda maddelerinin pazarlanması, pazarlama kanalları, sorunlar ve çözüm önerileri, satın alma davranışı gibi konularda birçok araştırma yapılmakla birlikte özellikle tüketicilerin e-ticaret yoluyla gida maddeleri satın almaya yönelik tutumları üzerine yapılmış çalışma sayısı çok sınırlıdır. Yapılacak araştırma ile bu konudaki önemli bir eksiklik giderilecektir.

$\mathrm{Bu}$ çalışmada, Tokat il merkezinde yaşayan tüketicilerin e-ticaret yoluyla gida maddeleri satın almaya yönelik tutumunu etkileyen faktörlerin analizi yapılmıştır. $\mathrm{Bu}$ bağlamda, araştırma ile e-ticaret yoluyla gıda maddeleri satın almaya yönelik olumlu ve olumsuz tutuma sahip tüketicilerin sosyoekonomik faktörlerinin belirlenmesi, olumlu tutuma sahip olmayı etkileyen faktörlerin analiz edilmesi ve internetten gida maddeleri satın alma tutumunu artıracak durumların tespit edilmesi amaçlanmıştır.

\section{Materyal ve Yöntem}

\subsection{Materyal}

Araştırmanın materyalini, Tokat-Merkez ilçedeki tüketiciler ile 2011 y1l içerisinde yüz yüze görüşme tekniği sonucu yapılan anketlerden sağlanan orijinal nitelikli veriler oluşturmaktadır.

\subsection{Yöntem}

Araştırma için öncelikle amaca göre hangi bilgilerin toplanması gerektiği ve bu verileri toplarken nasıl bir yöntem izlenmesi gerektiği belirlenmiştir.

Araştırmada anket uygulanacak tüketici sayısının tespiti amacıyla ilk olarak merkez ilçedeki tüketici sayısı belirlenmiştir. Anket yapılacak tüketici sayısını (örneklem sayısı) belirlemede aşağıdaki Eşitlik 1 kullanılmıştır (Arıkan 2007):

$$
n=\frac{\mathrm{N} \times \mathrm{t}^{2} \times \mathrm{p} \times \mathrm{q}}{\mathrm{D}^{2} \times(\mathrm{N}-1)+\mathrm{t}^{2} \times \mathrm{p} \times \mathrm{q}}
$$

Eşitlikte; n, örneklem sayısını; n, ana kütle sayısını; $\mathrm{p}$, incelenen birimin popülasyondaki oranını; q, 1 - p değerini; D, d/t değerini; d, kabul edilebilir hata payını; t, ilgili güven sınırındaki t değerini ifade etmektedir.

Örnek hacminin belirlenmesi için \%90 güven sınırı ve $\% 5$ hata payılla çalışılmış ve tüketicilerin e-ticaret yoluyla gıda maddeleri alımına yönelik tutumu oranı belli olmadığ için $\mathrm{p}$ ve q değerleri 0.5 alınarak örneklem sayısı 277 olarak belirlenmiştir. Araştırmada, tüketicilerin e-ticaret yoluyla gıda maddeleri satın almaya yönelik tutumları ölçülmek istendiğinden anket yapılan kişiler rastgele seçilmiştir.

Araştırmada anketlerden elde edilen veri ve bilgiler değerlendirilmeden önce anket formları üzerinde gerekli düzenlemeler yapılarak eksiklikler giderilmiş, sonra kodlanan veriler bilgisayara aktarılmıştır. Verilerin değerlendirilmesinde ise MS Office Excel ve Ewievs 5 paket programından yararlanılmıştır. Elde edilen veriler; basit aritmetik ortalama, frekans, yüzde dağılımı ile ortalama rank olarak ortaya konulmuş ve çizelgeler ile sunulmuştur.

Ekonometrik çalışmalarda, bağımlı değişkenin nitel olması durumunda sınırlı bağımlı değişken regresyon modelleri kullanılmaktadır. İki durumu gösteren bağımlı değişken bir olayın olma veya olmama durumunu ifade etmektedir. Olayın olma durumunda bağımlı değişken 1, olmama durumunda ise 0 değerini almaktadır. Bağımlı değişkeni açıklayan birçok bağımsız değişken olabilir (Gujarati 2006). Bu nedenle anketlerden elde edilen veriler 1şı̆̆ında, Tokat-Merkez ilçede yaşayan tüketicilerin e-ticaret yoluyla gıda maddeleri satın almaya yönelik tutumunu etkileyen faktörleri belirleyebilmek için Logit Modeli kullanılmıştır. Logit modelini açıklayan lojistik dağılım fonksiyonu aşağıdaki Eşitlik 2'de verilmiştir (Greene 2000). 
$P_{i}=E\left(Y_{i}=\frac{1}{X_{i}}\right)=\frac{1}{1+e^{-\left(\beta_{1}+\beta_{2} X_{i}\right)}}$

Yukarıdaki eşitlikten görülebileceği gibi $\mathrm{P}_{\mathrm{i}}$ ile $\mathrm{X}_{\mathrm{i}}$ arasındaki ilişki hem $\mathrm{X}_{\mathrm{i}}$ 'ye hem de katsayılara göre doğrusal değildir. Bu durumda sıradan en küçük kareler yöntemi ile tahmin yapılamaz, ancak bu sorun uygulanacak bazı işlemlerle doğrusal biçime dönüştürülebilir.

Yukarıdaki eşitliğin her iki yanı $\left(1+e^{-I_{i}}\right)$ ile çarpıldığında $\left(1+e^{-I_{i}}\right) P_{i}=1$ olur. $\mathrm{P}_{\mathrm{i}}$ 'ye bölüp 1 çıkarılarak $e^{-I_{i}}=\frac{1}{P_{i}}-1=\frac{1-P_{i}}{P_{i}}$ bulunur. $e^{I_{i}}=\frac{1}{e^{I_{i}}}$ olduğundan $e^{I_{i}}=\frac{P_{i}}{1-P_{i}}$ elde edilir. Son olarak eşitliğin her iki yanının doğal logaritması alındığında Eşitlik 3 elde edilir. Burada olasılık oranının logaritması olan $\mathrm{L}_{\mathrm{i}}$ hem katsayılara hem de bağımsız değişkene göre doğrusaldır (Özer 2004).

$$
L_{i}=\operatorname{Ln}\left(\frac{P_{i}}{1-P_{i}}\right)=l i=\beta_{0}+\beta_{1} X_{i}
$$

Bu durumda Logit modelindeki $\beta$ katsayıları eğimi, $X_{i}$ de bağımsız değişkenleri ifade etmektedir. Buna göre $X$ 'deki 1 birimlik değişim, bağımlı değişkendeki logaritmik oranı nasıl değiştirdiği tahmin edilebilir.

Logit model tahmin sonuçlarına dayalı olarak incelenebilecek bir başka husus da, bağımsız değişkendeki 1 birimlik değişim karşısında olasılık oranında meydana gelecek yüzde değişimin tespitidir. Bu, eğim katsayılarının ters logaritmaları alınıp, bundan 1 çıarılıp sonucun 100 ile çarpılmasıyla gerçekleştirilir (Özer 2004).

Çalışmada, tüketicilerin e-ticaret yoluyla gıda maddeleri satın almaya yönelik tutumunu etkileyen faktörleri belirleyebilmek için oluşturulan Logit modelde;

a) Bağımlı değişken olarak; anket yapılan tüm tüketicilerin e-ticaret yoluyla gıda maddesi satın almaya yönelik olumlu tutuma sahip olup olmama durumu (olumlu tutum $=1$, olumsuz tutum $=0$ ),

b) Bağımsız değişkenler olarak ise; gelir, toplam harcama, gıda harcaması, yaş, eğitim, internet bağlantısı, güven, tavsiye, daha önce alışveriş yapma, kullanım kolaylığı, haberdar olma ve maliyet değişkenleri dikkate alınmıştır. $\mathrm{Bu}$ değişkenlerin tanım ve kodları Çizelge 1'de verilmiştir.

\section{Çizelge 1- Bağımsız değişkenlerin tanımlanması}

Table 1-Definition of independent variables

\begin{tabular}{|c|c|}
\hline Değişkenler & Tanım ve kodlar \\
\hline Gelir & Aylık gelir (TL/ay/birey) \\
\hline Toplam harcama & Aylik toplam harcama (TL/ay/birey) \\
\hline G1da harcaması & Aylık gida harcaması (TL/ay/birey) \\
\hline Yaş & Yaş (y11/birey) \\
\hline Eğitim seviyesi & $\begin{array}{l}\text { 0=Okur-yazar değil, 1=Okur- } \\
\text { yazar, 2=̇̇lkokul, } 3=\text { Ortaokul, } \\
\text { 4=Lise, } 5=\text { =üksekokul, 6=Lisans, } \\
7=\text { Yüksek lisans, } 8=\text { Doktora }\end{array}$ \\
\hline $\begin{array}{l}\text { İnternet } \\
\text { bağlantıs1 }\end{array}$ & $\begin{array}{l}1=\text { İnternet bağlantısına sahip olan } \\
0=\text { İnternet bağlantısına sahip } \\
\text { olmayan }\end{array}$ \\
\hline Güvenme & $\begin{array}{l}1=\text { E-ticaret işlemlerine güvenen } \\
0=\text { E-ticaret işlemlerine } \\
\text { güvenmeyen }\end{array}$ \\
\hline Tavsiye & $\begin{array}{l}1=\text { Tavsiyede bulunulan } \\
0=\text { Tavsiyede bulunulmayan }\end{array}$ \\
\hline $\begin{array}{l}\text { Daha önce } \\
\text { alışveriş yapma }\end{array}$ & $\begin{array}{l}1=\text { Daha önce alışveriş yapan } \\
0=\text { Daha önce alışveriş yapmayan }\end{array}$ \\
\hline $\begin{array}{l}\text { Kullanım } \\
\text { kolaylığ } 1\end{array}$ & $\begin{array}{l}1=\text { İnterneti kolayca kullanan } \\
0=\text { İnterneti kolayca kullanamayan }\end{array}$ \\
\hline Haberdar olma & $\begin{array}{l}\text { 1=E-ticaret uygulamasından } \\
\text { haberdar olan } \\
0=\text { E-ticaret uygulamasından } \\
\text { haberdar olmayan }\end{array}$ \\
\hline Maliyet & $\begin{array}{l}1=\text { E-ticareti daha maliyetli } \\
\text { bulmayan } \\
0=\text { E-ticareti daha maliyetli bulan }\end{array}$ \\
\hline
\end{tabular}

\section{Bulgular ve Tartışma}

\subsection{Tüketicilerin sosyo-ekonomik özellikleri}

Anket yapılan tüketicilerin \%73.28'i erkek ve \%26.72'si kadın olup, \%75.81'i evli, \%14.44'ü bekâr ve \%9.75'i ise boşanmış-dul şeklindedir.

Tüketicilerin \%23.83'ü 30 yaş ve aşağı, \%42.60'1 31-40 yaş arası, \%26.71'i 41-50 yaş aras1 ve $\% 6.86$ ' 1 ise 51 yaş ve üzeridir. 
Tüketicilerin $\% 2.17$ 'sinin doktora, $\% 5.05$ 'inin yüksek lisans, \%16.24'ünün fakülte, \%17.33'ünün yüksekokul, \%29.25'inin lise, \%14.80'inin ortaokul, \%9.38'inin ilkokul mezunu oldukları, buna karşın $\% 5.42$ 'sinin sadece okur-yazar ve \%0.36'sının ise okur-yazar olmadığı saptanmıştır.

Anket yapılan kişiler en fazla memurlardan oluşmakta (\%26.72) olup bunu sirasıyla esnaflar (\%16.97), işçiler (\%15.88), öğrenciler (\%11.91), emekliler (\%8.66), ev hanımları (\%8.30), çiftçiler $(\% 6.86)$ ve serbest meslek sahipleri $(\% 4.70)$ izlemektedir.

Tüketicilerin çoğunluğunun (\%49.10) ailelerinin 3 ile 4 kişiden oluştuğu tespit edilmiştir. Bunu sırasıyla, 1-2 kişi $(\% 28.52)$ ile 5 ve daha fazla kişiden (\%22.38) oluşan aileler izlemektedir.

Görüşülen bireylerin çoğunluğunun (\%47.30) 1000 TL ve düşük aylık gelire sahip olduğu, bunu sirasiyla 1001-2000 TL arası (\%45.13), 2001-3000 TL arası (\%5.41) ile 3001 TL ve üzeri (\%2.16) aylık gelire sahip bireylerin takip ettiği belirlenmiştir. Tüketicilerin aylık harcamas1; \%54.51 ile 501-1000 TL aras1, \%27.80 ile 1001-2000 TL aras1, \%14.44 ile 1501-2000 TL aras1, \%1.80 ile 500 TL ve daha az, \%1.45 ile de 2001 TL ve daha fazla şeklindedir. Aylık gıda harcama tutarı ise; \%35.38 ile 400 TL ve aşağı, \%35.38 ile 401-600 TL arası, \%18.05 ile 601-800 TL aras1, \%10.47 ile 801-1000 TL aras1 ve $\% 0.72$ ile de 1000 TL'den fazladır.

\subsection{Tüketicilerin internet bağlantısına sahip olma ve internet kullanma durumu}

Tüketicilerin \%57.76'sının (\%63.12'sinin işyerinde, $\% 30.63$ 'ünün kendi evinde ve $\% 6.25$ 'inin ise hem kendi evi hem de işyerinde) internet bağlantısına sahip olduğu saptanmıştır. Buna karşın tüketicilerin \%79.78'inin interneti kullanmakta oldukları, buna karşın \%20.21'inin ise hiçbir şekilde interneti kullanmadıkları belirlenmiştir. İnternet kullanıcılarının \%38.46's1 interneti her gün kullanmakta, \%37.10'u haftada bir kereden fazla, $\% 6.34$ 'ü haftada bir kere ve $\% 18.10$ 'u ise interneti nadiren kullanmaktadır.
İnternet kullanan tüketicilerin interneti kullanım nedenleri arasında ilk sırayı \%33.94'lük oranla gazete vb. okumak alırken, bunu sirasıyla \%33.03 ile kişiler ile iletişim kurma, \%19.90 ile her türlü alışveriş yapma, \%9.05 ile değişik konularda bilgi toplama, \%1.80 ile film izleme, \%1.36 ile eğlenme ve son sırada ise $\% 0.45$ ile ticari amaçlı kullanım (fatura ödeme, havale alma-yapma gibi) takip etmektedir. Bu veriler, internetin çok amaçlı kullanıldığını göstermektedir.

İnternet kullanmayan tüketicilerin nedenleri; bilgisayar sahibi olunmaması (\%29.78), kullanım maliyetinin yüksekliği (\%22.34), ihtiyaç hissetmeme (\%14.90), internetin olumsuzluklarından sakınma (\%11.70), alışkın olmama (\%10.64) ve internet kullanımını bilmeme $(\% 10.64)$ olarak tespit edilmiştir. Tüketicilerin \%70.58'inin interneti kolayca kullanabildiği saptanmıştır.

\subsection{Tüketicilerin e-ticaret uygulamasindan haberdar olma durumu}

Tüketicilerin büyük bir kısmının (\%71.84) e-ticaret uygulamasından haberdar oldukları tespit edilmiştir. E-ticaret kavramı, kişiler tarafından farklı algılanmakta ve/veya tanımlanmaktadır. Bu kapsamda, tüketicilerin e-ticareti nasıl algıladıkları ve/veya tanımladıkları tespit edilmiştir. E-ticaret, tüketicilerin \%57.29'una göre “internetten yapılan alışveriş", \%9.55'ine göre "alışverişin kredi kartı ile yapılması", \%9.04'üne göre "mal ve hizmetlerin üretim, tanıtım, satış, sigorta, dağıtım ve ödeme işlemlerinin bilgisayar ağlart üzerinden yapılması", \%7.03'üne göre "elektronik eşya satışı", \%7.03'üne göre "ticaretin elektronik ortamda yapılması", \%4.53'üne göre "ticari işlemlerin sanal âlemde yapılması" iken \%5.53'ü ise bu konuda herhangi bir fikirlerinin olmadığını belirtmişlerdir.

\subsection{Tüketicilerin e-ticaret işlemlerine güvenme durumu}

Tüketicilerin \%65.36'lık kısmının internet üzerinden yapılan e-ticaret işlemlerine güven duymadıkları saptanmıştır. E-ticaret işlemlerine güvenmeyen tüketicilerin güvenmeme nedenleri; $\% 40.88$ ile kişisel bilgilerin çalınma ihtimalinin olması, 
\%37.02 ile karşı tarafı tanımama, \%36.46 ile daha önce alışveriş yapmama, \%7.73 ile sipariş edilen ürünle alınan ürünün şeklinin farklı olması, \%6.08 ile sipariş edilen ürünle alınan ürünün renginin farklı olması, \%4.42 ile sipariş edilen ürünle alınan ürünün görüntüsünün farklı olması ve $\% 2.76$ ile de sipariş edilen ürünün transferinde kontrol olmaması olarak tespit edilmiştir.

E-ticaret işlemlerine güvenen tüketicilerin (\%34.66) güven duyma nedenleri olarak ise; \%32.29 ile şimdiye kadar internetten alışveriş yapıldığında herhangi bir problem yaşanmaması, \%30.20 ile alıcı ve satıcı arasında sözleşme yapılması, \%26.05 ile tüketicinin kendisini mal satışı yapan firmaya güvenmek zorunda hissetmesi, $\% 9.38$ ile tüketicinin e-ticaretin güvenilir olduğuna inanması, \%1.04 ile tüketicinin mal satın aldığ firmanın güvenilir olduğuna inanması olarak tespit edilmiş iken, $\% 1.04$ 'ü ise bu konuda herhangi bir fikirlerinin olmadığını belirtmişlerdir.

\subsection{Tüketicilerin e-ticaret yoluyla glda maddesi satın almayı uygun bulma durumu}

Tüketicilerin \%62.46’lık bölümünün e-ticaret yoluyla gida maddesi satın almayı uygun bulmadıkları saptanmıştır. Bunun en belirgin nedeni olarak ise tüketicilerin e-ticarete karşı güven duygusuna sahip olmaması gösterilebilir. Aynı durum, e-ticaret yoluyla gıda maddesi dışındaki diğer malların satın alınmasında da bazı tüketicilerin değişik nedenlerle bu şekildeki alışverişe karşı olumsuz yaklaştıkları görülmüştür.

\subsection{Tüketicilere e-ticaret yoluyla gıda maddesi satın alımında tavsiyede bulunulma durumu}

Tüketicilerin \%73.65'lik kısmına e-ticaret yoluyla gıda maddesi satın alımı konusunda tavsiyede bulunulduğu saptanmıştır. E-ticaret yoluyla ürün satın alan tüketicilerin aldıkları ürün yelpazesindeki gıda maddelerinin payına (\%4.02) bakıldığında, tavsiyede bulunulmayan tüketici oranın yüksek olması normaldir.

\subsection{Tüketicilere göre gıda maddeleri temin yollarınin maliyetli olma durumu}

Tüketicilerin \%81.23'lük bir bölümünün geleneksel yollardan (alıcı ve satıcının yüz yüze görüşmesi suretiyle alışveriş yapılması gibi) ziyade internet vasıtasıyla gıda maddesi temininin daha maliyetli buldukları tespit edilmiştir. Internet ile alışverişte; ürün nakliyesinde taşıma (kargo gibi) ücreti olması, pazarlık yapılamaması gibi bazı tüketiciler açısından olumsuzluklar söz konusudur.

\subsection{Tüketicilerin e-ticaret yoluyla gıda maddeleri alışverişinin yaygınlaşması konusundaki düşüncelerine göre durumu}

Tüketicilerin \%53.43'ü e-ticaret ile gida maddeleri alışverişinin yaygınlaşacağını, buna karşın \% 47.57'si ise yaygınlaşamayacağını ifade etmişlerdir.

E-ticaret yoluyla gıda maddeleri alışverişinin yaygınlaşacağ 1 düşüncesine sahip olan tüketicilerin \%37.16's1 bunun nedeni olarak e-ticaretin diğer sektörlerde de yaygınlaşmasını belirtmiş iken, \%27.70'i geleneksel ticaretin modasının geçmekte olduğunu, \%16.89'u istatistiklerin e-ticaretin yaygınlaştığını göstermesi ve \%11.49'u Yeni Ticaret Kanunu'nun şirketlere internet sayfasını kurmalarını şart koşmasını (bu sayede şirketler firma ile ilgili tüm bilgileri sunabilecek, aynı zamanda internet üzerinden alışveriş yapabilecektir) ifade etmişlerdir. Buna karşın, tüketicilerin \%6.76'sının bu konuda herhangi bir fikirlerinin olmadığı saptanmıştır.

E-ticaret yoluyla gıda maddeleri alışverişinin yaygınlaşmayacağı düşüncesi hâkim olan tüketiciler ise bunun nedenlerini; en başta \%27.91 ile e-ticaretin Tokat ilinde yaşayan insanların yapisina uygun olmaması olmak üzere \%17.05 ile e-ticareti gereksiz görmesi, \%13.18 ile e-ticareti imkânsız bulması, \%7.75 ile e-ticarette müşteri memnuniyetinin sağlanamayacağı düşüncesi ve $\% 1.55$ ile de e-ticaretin gıda maddeleri için uygun olmaması olarak beyan etmişlerdir. Bununla birlikte, tüketicilerin \%32.56'l1k bir bölümünün bu konuda herhangi bir fikre sahip olmadığı saptanmıştır. 


\subsection{Tüketicilerin e-ticaret yoluyla ürün satın alma durumu}

Tüketicilerin \%57.04'ünün daha önce e-ticaret yoluyla herhangi bir ürün (bilgisayar, kitle iletişim araçları, vb.) satın aldığı, buna karşın \%42.96'lık kesimin ise ürün satın almadığ 1 belirlenmiştir. $\mathrm{Bu}$ durum, tüketicilerin yaklaşık yarısının halen e-ticarete mesafeli durduklarını göstermektedir.

İnternetten alışveriş yapan tüketicilerin e-ticaret yoluyla satın aldıkları ürünler incelendiğinde, tüketiciler en fazla seyahat için bilet satın alırken (\%29.11), bunu sirasiyla kitap (\%21.52), giysi $(\% 20.25)$, bilgisayar $(\% 18.35)$, kozmetik ürünleri (\%17.72), telefon (\%15.82), mobilya (\%7.59), oyuncak (\%6.33), beyaz eşya $(\% 6.33)$, gıda maddesi (\%5.06), elektronik eşya (\%2.53), kontör $(\% 0.63)$ ve bilgisayar programı $(\% 0.63)$ satın alma izlemektedir. Gıda maddesinin genel içindeki payının düşük olmasının başlıca nedeni, gıda sektöründe e-ticaret alanındaki yatırımların henüz tamamlanmaması olabilir.

E-ticaret yoluyla ürün satın alan tüketicilerin $\% 41.88$ 'inin $1-2 \mathrm{kez}$ arası ürün satın aldığı tespit edilmiş iken, \%26.25'inin $11 \mathrm{kez}$ ve daha fazla, \%11.87'sinin 7-10 kez aras1, \%11.25'inin 3-4 kez arası ve \%8.75'inin de 5-6 kez arası ürün satın almışlardır.

Tüketicilerin e-ticaret yoluyla ürün satın alma nedenleri arasında birinci sırayı ürünü seçebilme olanağının olması (\%37.15) almaktadır. Diğer nedenler ise, sırasıyla; bu şekilde satın alınan ürünün daha ucuz olması (\%31.15), satın alınan ürünü karşılaştırma imkânının olması (\%13.11), ihtiyaç hissetme (\%8.21), ürün hakkında detaylı bilginin olması (\%5.46) ve ürüne ulaşımının daha hizlı olmasidır (\%4.92).

E-ticaret yoluyla ürün satın almamış olan tüketicilerin (\%42.96) nedenleri ise; bu şekilde alışveriş yapmaya güvenmeme (\%54.62), konu hakkında yeterince bilgi sahibi olunmaması (\%30.25), bilinen yerlerden alışveriş yapma isteği (\%30.25), kredi kartı bilgilerinin çalınabilme endişesi (\%18.49), fiyatların yüksek olması (\%10.92), ihtiyaç hissetmeme (\%10.08), ürünleri görme ve dokunma isteği (\%8.40), çabuk bozulan ürünler için bu şekilde alışverişin uygun olmadığını düşünmesi (\%8.40), ürünleri deneme imkânının olmaması (\%5.88), ürünün iade imkânının olmaması (\%5.04), teknik servis imkânının olmaması (\%1.68), gerek duymama (\%1.68) ve teslimat giderlerinin yüksek olması (\%0.84) şeklinde tespit edilmiştir.

\subsection{E-Ticaret yoluyla gida maddesi satın almayı uygun bulmayan tüketicilerin tutumlarını olumlu yapacak faktörler}

Tüketiciler internetten alışveriş yaparken veya yapmak isterken birçok faktörü dikkate almaktadır. Diğer bir ifadeyle, tüketicilerin e-ticaret yoluyla özellikle gıda maddesi satın alma isteğini artırmak için dikkat edilmesi gereken faktörler bulunmaktadır. $\mathrm{Bu}$ bağlamda, internetten gida maddesi satın alma istekliliğini artırmak için tüketicilerin önem verdiği faktörler ve bu faktörlerin önem dereceleri incelendiğinde, e-ticaret yoluyla gıda maddesi satın almaya yönelik tüketicilerin tutumunu arttıracak en önemli faktör güven duygusu, buna karşın en önemsiz faktör ise satın alınan ürünün adrese teslimat olmasıdır (Çizelge 2).

Çizelge 2- Tüketicilerin e-ticaret yoluyla gıda maddesi satın alma isteğini artırıcı faktörler ve önem seviyeleri

Table 2- Factors and significant levels promoting the purchasing desire of consumers through e-commerce

\begin{tabular}{lc}
\hline Faktörler & $\begin{array}{c}\text { Ortalama } \\
\text { rank }^{*}\end{array}$ \\
\hline Güvenme & 2.67 \\
Maliyetinin düşük olması & 3.46 \\
Kredi kartı bilgilerinin istenmemesi & 3.89 \\
İhtiyaç duyma & 4.40 \\
Dağıtımın hızlı olması & 5.27 \\
Ekonomik anlamda avantajlı olması & 5.46 \\
Tavsiye edilmesi & 6.63 \\
Kolay olması & 7.26 \\
E-ticaret hakkında bilginin olması & 7.40 \\
Adrese teslimat olması & 8.16 \\
\hline
\end{tabular}

*1, en önemli, ... 10, en önemsiz 
Çizelge 3- Logit model sonuçları

Table 3-Logit model outputs

\begin{tabular}{|c|c|c|c|c|}
\hline \multicolumn{5}{|l|}{ Bağımlı değişken: Tutum } \\
\hline Bă̆ımsız değişkenler & Katsayl & Std. hata & $z$ - Istatistik & $P$ \\
\hline Aylık gida harcaması & 0.001 & 0.000 & 2.052 & $0.000^{\mathrm{a}}$ \\
\hline Eğitim & 0.317 & 0.101 & 3.128 & $0.040^{\mathrm{b}}$ \\
\hline Güven & 1.093 & 0.297 & 3.674 & $0.001^{\mathrm{a}}$ \\
\hline Gelir & 1.076 & 0.301 & 3.574 & $0.084^{\circ}$ \\
\hline Toplam harcama & 2.003 & 0.467 & 4.289 & 0.108 \\
\hline Yaş & -1.550 & 0.475 & -3.263 & -0.145 \\
\hline İnternet bağlantısı & 4.484 & 0.812 & 5.522 & 0.147 \\
\hline Tavsiye & 0.467 & 0.277 & 1.686 & 0.164 \\
\hline Daha önce alışveriş yapma & 2.391 & 0.903 & 2.647 & 0.341 \\
\hline Kullanım kolaylığı & 1.284 & 0.931 & 1.379 & 0.675 \\
\hline Haberdar olma & 1.347 & 1.029 & 1.310 & 0.785 \\
\hline Maliyet & -6.327 & 2.466 & -2.566 & -0.961 \\
\hline Sabit terim $(\mathrm{C})$ & -3.033 & 0.515 & -5.882 & $0.000^{\mathrm{a}}$ \\
\hline
\end{tabular}

Log likelihood: -155.9503 Restr. Log likelihood: -183.3167

McFadden R-squared: 0.149285 Probability (LR stat) : 0.0000

a, \%1 önem düzeyinde; b, \%5 önem düzeyinde; c, \%10 önem düzeyinde anlamlıdır.

\subsection{Logit modelde tüketicilerin e-ticaret yoluyla gıda maddeleri satın almaya yönelik tutumunu etkileyen faktörlere ait bulgular}

Tüketicilerin e-ticaret yoluyla gıda maddeleri satın almaya yönelik tutumu ile buna etki eden faktörler arasındaki ilişkiyi gösteren model sonuçları Çizelge 3 'te verilmiştir. Belirlenen bağımsız değişkenlerden, aylık gıda harcaması ve güven istatistiksel olarak $\% 1$, eğitim ise $\% 5$ önem düzeyinde anlaml bulunmuştur.

Anket çalışması sonucu elde edilen veriler ile yapılan Logit model sonuçlarına göre; tüketicilerin e-ticaret yoluyla gida maddeleri satın almaya yönelik tutumunu etkileyen değişkenlerden birisi tüketicinin aylık gıda harcamasıdır. Aylık gida harcaması değişkeni \%1 düzeyinde istatistiksel olarak önemlidir. Aylık gıda harcaması değişkeninin katsayısı pozitif değer almıştır. Bu durumda aylık gıda harcaması arttıkça tüketicilerin e-ticaret yoluyla gıda maddeleri satın almaya yönelik olumlu tutuma meyilli olma olasılı̆̆ını artıracağı söylenebilir.

Logit modelde tüketicilerin e-ticaret yoluyla gıda maddeleri satın almaya yönelik tutumunu etkileyen bir diğer değişken tüketicinin eğitim düzeyidir. $\mathrm{Bu}$ değişken \%5 düzeyinde istatistiksel olarak önemli bulunmuştur. Eğitim değişkenin katsayısı modelde pozitif işaretlidir. Bu durumda eğitim seviyesinin bir kademe yükselmesi tüketicilerin olumlu tutuma sahip olma olasılığının artacağı söylenebilir.

Model dâhilinde belirlenen bağımsız değişkenlerden bir diğeri de tüketicinin e-ticaret işlemlerine karşı duyduğu güvendir. Bu değişken \%1 düzeyinde istatistiksel olarak önemli bulunmuştur. $\mathrm{Bu}$ değişkene ait katsayının pozitif işaretli olması, değişken tarafindan tüketicilerin e-ticaret yoluyla gıda maddesi satın almaya yönelik olumlu tutuma sahip olma olasılığını artıracağı söylenebilir. 
Logit modele göre, diğer şartlar sabit varsayımı altında, aylık gida harcaması 1 birim arttığında tüketicilerin olumlu tutuma sahip olma log-olasılık oranı 0.001 artacak, eğitim seviyesinin 1 kademe yükselmesi durumunda tüketicilerin e-ticaret yoluyla gıda maddeleri satın almaya yönelik olumlu tutuma sahip olma log-olasılık oranını 0.317 arttıracak ve tüketicilerin e-ticaret uygulamasına güvenmeleri halinde olumlu tutum gösterme olasılığ 1.093 kadar yükselecektir.

Logit model tahmin sonuçlarına dayalı olarak incelenebilecek bir başka husus da bağımsız değişkendeki 1 birimlik değişim karşısında olasılık oranında meydana gelecek \% değişimin tespitidir. $\mathrm{Bu}$, eğim katsayılarının ters logaritmaları alınıp, bundan 1 çıkarılıp sonucun 100 ile çarpılmasıyla gerçekleştirilir (Özer 2004).

$$
\begin{aligned}
& \mathrm{e}^{0.001}=1.001=(1.001-1) \times 100=0.10 \\
& \mathrm{e}^{0.317}=1.373=(1.373-1) \times 100=37.30 \\
& \mathrm{e}^{1.093}=2.983=(2.983-1) \times 100=198.32
\end{aligned}
$$

Bulunan sonuçlara göre; diğer şartlar sabit varsayımı altında, aylık gıda harcamasındaki 1 birimlik artışa karşılık olasılık oranı $\% 0.10$ artarken, eğitim seviyesinin 1 tabaka yükselmesi olasılık oranını $\% 37.30$ arttıracak ve güven ortamının oluşturulması durumunda tüketicilerin olumlu tutuma sahip olma olasılık oranı \%198.32 artacaktır.

Modelin açıklama gücünü ifade eden McFadden R-kare 0.149285 olarak belirlenmiştir. Genelde olduğu gibi burada da oldukça düşük çıkan bu istatistik 0 ile 1 arasında bir değer almaktadır ve doğrusal regresyon modelindeki $\mathrm{R}^{2}$ gibi yorumlanmamaktadır (Özer 2004). Bu değer, modele dâhil edilen değişkenlerin tüketicilerin e-ticaret yoluyla gıda maddeleri satın almaya yönelik tutumları ile ilgili tercih olasılıklarını açıklamada yeterli olduğunu göstermektedir. Bununla beraber model, $\mathrm{F}$ test istatistiğinin eş değeri olan olabilirlik istatistiğine göre \%1 düzeyinde önemli bulunmuştur.

\section{Sonuçlar}

Araştırma sonuçlarına göre, tüketicilerin önemli bir kısmının alışveriş yapma da dâhil olmak üzere çok değişik amaçlar için internet kullandığı saptanmıştır. Ancak e-ticaret işlemlerine başta kişisel bilgilerin çalınma ihtimalinden dolayı çoğunlukla güvenilmediği belirlenmiştir. Çalışma sonucunda tüketicilerin önemli bir bölümünün e-ticaret yoluyla gıda maddesi alımını uygun bulmaması nedeniyle tanitıcı faaliyetlere önem verilmelidir. Ayrıca Logit model sonuçlarına dayanılarak; tüketicilerin e-ticaret yoluyla gıda maddesi satın almaya yönelik tutumunu etkileyen en önemli faktörler olan aylık gıda harcamasının, eğitim seviyesinin ve güven duygusunun artması, tüketicilerin e-ticaret yoluyla gıda maddesi satın alımına yönelik tutumunu olumlu etkileyeceği söylenebilir. Bunun için özel ve kamu kurum/kuruluşları ile gönüllü örgütler tarafından beslenme bilincinin oluşması için programlar düzenlenmeli ve eğitime gereken değer verilerek, e-ticaret için olmazsa olmaz olan güven ortamı oluşturulmalıdır. Ayrıca, gıda ürünlerini internet üzerinden pazarlayacak firmaların müşteri memnuniyetini sağlayacak faktörlere (ürünün kalitesi, görünürlüğü, tazeliği, fiyatı, ulaşımı, geri iadesi gibi) gerekli önemi vermeleri ile e-ticaret altyapılarını güçlendirmeleri halinde bu alışveriş şeklinin daha da yaygınlaşacağı söylenebilir.

\section{Kaynaklar}

Akıncı S (2002). Elektronik ticarette pazarlama stratejileri ve bir uygulama. Yüksek lisans tezi, Akdeniz Üniversitesi Sosyal Bilimler Enstitüsü İşletme Anabilim Dalı (Basılmamış), Antalya

Aksoy R (2006). Bir pazarlama değeri olarak güven ve tüketicilerin elektronik pazarlara yönelik tutumları. Zonguldak Karaelmas Üniversitesi Sosyal Bilimler Dergisi 4: 79-90

Albayrak M (2008). Gida pazarlamasinda e-ticaretin uygulanma şekilleri ve olası gelişmeleri. VIII. Ulusal Tarım Ekonomisi Kongresi. Bildiriler: 248-260, 2527 Haziran, Bursa

Arıkan R (2007). Araştırma Teknikleri ve Rapor Hazırlama. Asil Yayın Dağıtım, Ankara

Boyacıgil B (2008). İnternette pazarlama açısından müzayede siteleri ve tüketicilerin müzayede siteleri hakkındaki tutumları. Yüksek lisans tezi, Yıldız Teknik Üniversitesi Sosyal Bilimleri Enstitüsü İşletme Anabilim Dalı (Basılmamış), İstanbul 
Çağlar M (2009). Dünya ve Türkiye'de yeni ekonominin etkileri ve eleştirileri. Yüksek lisans tezi, Karamanoğlu Mehmetbey Üniversitesi Sosyal Bilimler Enstitüsü İşletme Anabilim Dalı (Basılmamış), Karaman

Doğaner M (2007). Elektronik ticaret Türkiye'de elektronik ticaretin gelişimi ve işletmeden tüketiciye elektronik ticaret üzerine bir araştırma. Yüksek lisans tezi, Selçuk Üniversitesi Sosyal Bilimler Enstitüsü İşletme Anabilim Dalı (Basılmamış), Konya

Ene S (2007). İnternet üzerinden alışverişte tüketici davranışlarını etkileyen faktörler: güdülenme üzerine bir uygulama. Doktora tezi, Marmara Üniversitesi Sosyal Bilimler Enstitüsü İşletme Anabilim Dalı (Basılmamış), İstanbul

Greene W H (2000). Ekonometric Analysis. Englewood Cliffs, NJ: Prentice Hall

Gujarati D N (2006). Temel Ekonometri. (Çeviren: Ü Şenesen \& G G Şenesen), Literatür Yayıncılık, İstanbul

Kaya G H (2002). Türk Tarım Sektöründe E-Ticaret Fırsatları ve Potansiyel Sorunlar. Tarım ve Köyişleri Bakanlığı Araştırma Planlama ve Koordinasyon
Kurulu Başkanlığı Pazarlama ve Dış Ticaret Daire Başkanlığı, Ankara

Kılıç E C (2010). E-Pazarlama internet üzerinden pazarlama ve yöntemleri üzerine bir araştırma. Yüksek lisans tezi, Marmara Üniversitesi Sosyal Bilimler Enstitüsü Gazetecilik Anabilim Dalı (Basılmamış), İstanbul

Özer H (2004). Nitel Değişkenli Ekonometrik Modeller. Nobel Yayın Dağıtım, Ankara

Soydan R (2008). Tüketicilerin online alışverişe yönelik risk ve fayda algılamaları: geleneksel ve online tüketicilerin karşılaştırılması. Yüzüncü Yıl Üniversitesi Elektronik Sosyal Bilimler Dergisi 7(23): 386-402

Taşliyan M (2006). Elektronik Ticaret Kavramlar ve Uygulamalar. Sakarya Kitabevi, Kahramanmaraş

Uygur E (2010). E-Ticaret ve Türkiye'deki durumu. Yüksek lisans tezi, Ankara Üniversitesi Sosyal Bilimler Enstitüsü İşletme Anabilim Dalı (Basılmamış), Ankara

Yazıc1 A (2002). E-ticaretin ekonomik boyutu. Eskişehir Anadolu Üniversitesi İktisadi ve İdari Bilimler Fakültesi Dergisi 18 (1-2): 86-93 